\section{Identification of the Sava River temperature influence on the groundwater temperature of the Zagreb and Samobor-Zaprešić aquifers as a part of shallow geothermal potential}

The Mining-Geology-Petroleum Engineering Bulletin UDC: $626 / 627: 556.3$ DOI: 10.17794/rgn.2018.5.6 (filled by editors)

Original scientific paper

\author{
Josipa Kapuralić'; Kristijan Posavec'; Tomislav Kurevija3; Marija Macenićc \\ 1,2,3,4 Faculty of Mining, Geology and Petroleum Engineering, University of Zagreb, Pierottijeva 6, 10000 Zagreb
}

\begin{abstract}
:
Based on the statistical analysis of the time series of data, the influence of the change of the Sava River temperature on the changes of the groundwater temperature of the Zagreb and Samobor-Zaprešić aquifers is described. In the analysis, data was used from daily measurements of the Sava River temperature and from the quarterly measurements of the groundwater temperature. Statistical methods of correlation and linear regression were applied and the maximum, mean and minimum groundwater temperatures were analysed. The obtained results are presented in the form of statistical parameters, diagrams and maps of isotherms. This data is indispensable for the development of shallow geothermal applications related to open loop groundwater heat pump systems. Since the efficiency of a heat pump is directly dependent on the source temperature, the presented analyses are necessary for a prefeasibility study of geothermal projects and a comparison between different designs. Furthermore, currently operating projects in the Zagreb and Samobor-Zaprešić area are systematically elaborated, giving a first approximation of energy consumption from this renewable energy resource.
\end{abstract}

Keywords:

shallow geothermal energy, groundwater temperature, open loop heat pumps

\section{Introduction}

The identification of temperature fluctuations of the Sava River and groundwater temperature oscillations of the Samobor-Zaprešić and Zagreb aquifers are needed for the development of shallow geothermal energy applications. Such open loop groundwater energy systems usually consider the use of heat pumps and are capable of covering heating and cooling needs throughout the year. Groundwater temperature directly affects the level of the seasonal performance factor of a heat pump system, especially if passive cooling is used. Daily temperature fluctuations of the surface water body are damped, while season fluctuations could affect groundwater temperatures at closer distances to the Sava River, located in the area of both aquifers. This is mainly influenced by hydrologically favorable periods, i.e. longer periods of high water levels during which groundwater recharge occurs. Investigations of the relationship between a river and groundwater temperature are mostly based on numerical modelling, but difficulty in temperature analysis by numerical methods shows the need of a precise definition of the conceptual model as well as many input parameters. Therefore, for the area of the SamoborZaprešić and Zagreb aquifer systems, time series data of

Corresponding author: Josipa Kapuralić

josipa.kapuralic@rgn.hr the Sava River temperatures and groundwater temperatures were analyzed by statistical methods for the purpose of improving the conceptual model and obtaining a more complete picture of the connection between groundwater and surface waters.

\section{Geological and hydrogeological aspects of the Zagreb aquifer}

The Zagreb and Samobor-Zaprešić aquifer systems are located in Northwest Croatia and include urban areas and their surroundings (see Figure 1). The aquifers are composed mainly of Quaternary sediments, i.e. Middle and Upper Pleistocene and Holocene, which are described in the explanatory notes for the Basic Geological Map of SFRY 1:100 000 (Basch, 1983; Šikić et al., 1979). Mountains surrounding this area were subjected to intensive erosion and denudation in the Middle and Upper Pleistocene. The eroded material was transported by waterways and deposited into lakes and swamps (Velić and Saftić, 1991). In Holocene, climatic and tectonic processes allowed for the formation of the Sava River flow, which started transporting materials from the Alpine region. The Pleistocene sediments were formed in a lacustrine-marshy environment while the origin of the Holocene sediments is fluviatile. Variations in depositing conditions due to climate changes and tectonic pro- 


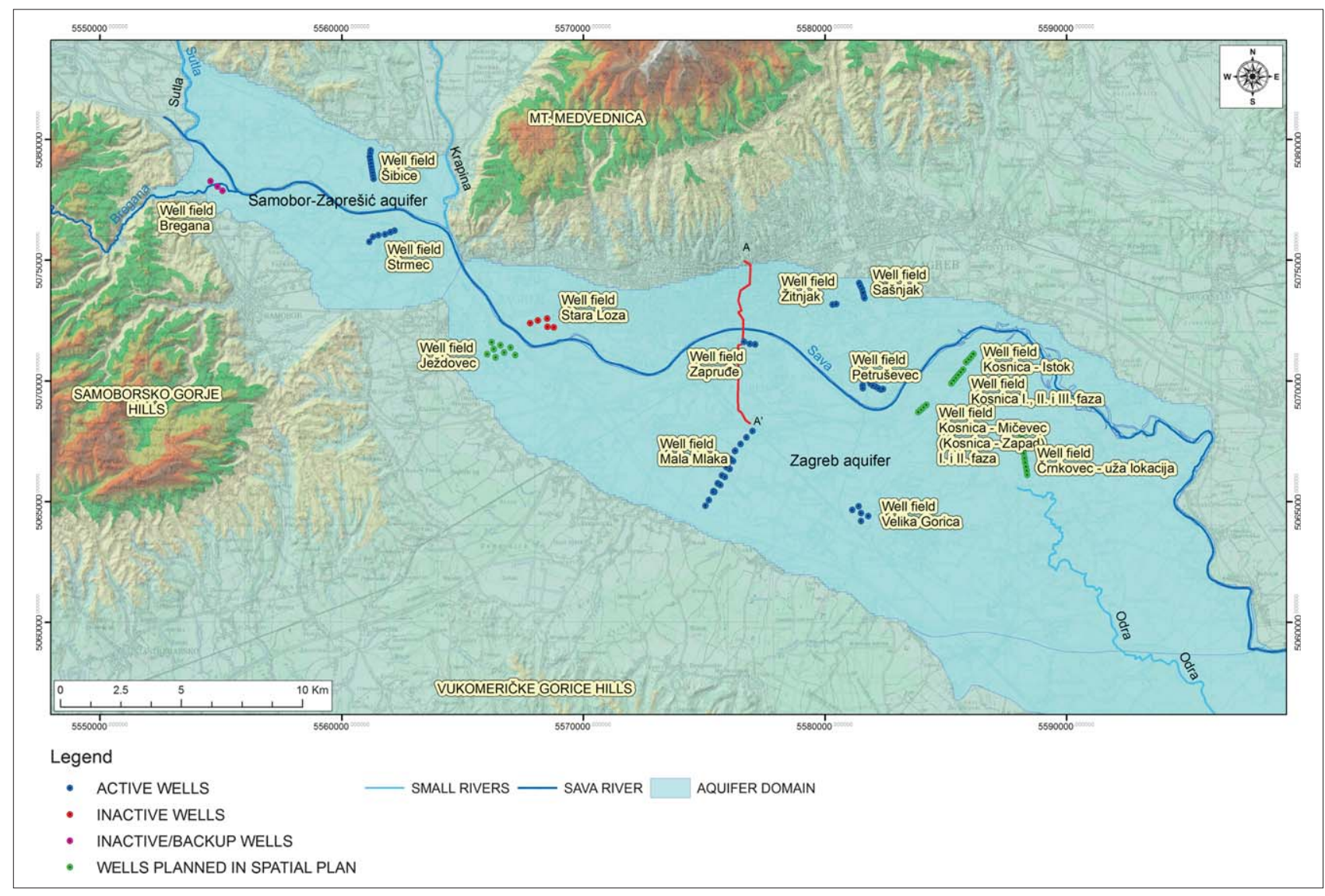

Figure 1. Position of the Samobor-Zaprešić and Zagreb aquifer with main well fields for the production of drinking water

cesses caused heterogeneity and anisotropy of the aquifer system (Velić and Durn, 1993; Velić et al. 1999).

From a hydrogeological point of view, the system is an alluvial unconfined aquifer with a water table connected to the Sava River. Horizontal spreading is determined by Quaternary deposits, which in turn define the aquifer domain (see Figure 1).

Quaternary sediments are divided into three main units: a clay and silt overburden; a shallow Holocene age aquifer made of medium-grain gravel mixed with sands; and a deeper, Middle and Upper Pleistocene aquifer consisting of gravel, sand and clay alternating in lateral and vertical directions. Differentiation between the shallow and deeper aquifers is stratigraphic since they are hydraulically connected and form a unique aquifer from a hydrogeological point of view. A characteristic hydrogeological profile of the Zagreb aquifer is shown in Figure 2 (for the profile position, see Figure 1). Overburden deposits are very thin and often not even present, while the thickness of the aquifers is in the range of 5 meters in the furthermost western part to about sixty meters in the eastern part of the Samobor-Zaprešić aquifer and about a hundred meters in the eastern part of the Zagreb aquifer. The regional groundwater flow direction is from west/northwest to east/southeast i.e. parallel to the Sava River. Local groundwater flow directions depend, to a large extent, on the hydrologic conditions and the Sava River water levels. Given that the flow of the Sava River, in the area of the studied aquifers, shows the characteristics of a valley river, it does not drain aquifers to the dominant extent as is the case in the upper parts of the flow. Head contour map analysis (Posavec, 2006) showed that during high river water levels, infiltration to groundwater takes place throughout the whole Zagreb aquifer area. Analysis also showed that during medium and low water levels, groundwater is drained in some parts of the flow. Spatial identification of parts of the aquifer systems, which are strongly controlled by the Sava River, was carried out by recession curve model analysis (Posavec, 2006). Analysis of the regression models showed that logarithmic regression predominates in parts of the aquifer close to the river, while in other parts, polynomial regression prevails. Generally, the hydraulic connection between the Sava River and the aquifer is very strong since the river is carved, along the entire flow through the Zagreb and Samobor-Zaprešić aquifers, into alluvial Holocene deposits with mainly high values of hydraulic conductivity.

The groundwater quantity in the Zagreb aquifer system is in a slow and constant decline. Posavec (2006) showed that groundwater levels are below upper elevations of the well screens and according to Bačani et al. (2010) groundwater levels are declining at an average of $1-2$ m every 10 years. The reason for this decline mostly 


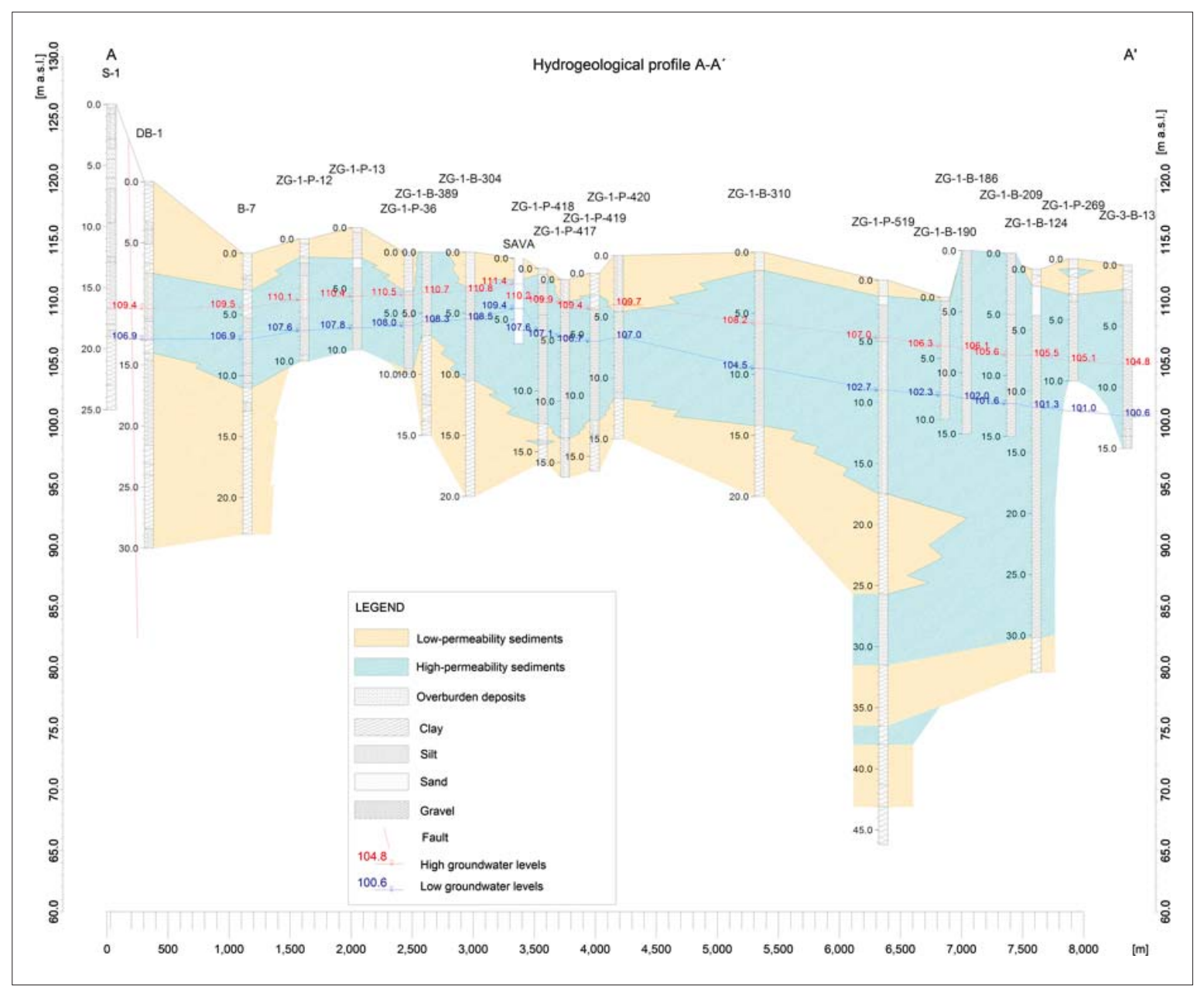

Figure 2. Characteristic hydrogeological profile A-A' (shown in Figure 1.) of the Zagreb aquifer

lies in the deepening and erosion of the Sava River bed over time. A minor effect has also been the construction of levees for protection from flooding, as well as groundwater exploitation for the needs of public water supply, while industry to a lesser extent affects the decline of groundwater levels, if compared to the first two causes. In the near future, there are already plans to construct a series of river dams to stop the negative trends of water table decline. Comprehensive analyses and overviews of the aquifer groundwater level decline were given by Posavec (2006), Posavec et all. (2017) and Vujević \& Posavec (2018).

This area has a marine west coast climate, with four separate seasons. It is a mild climate with warm summers and cold winters, without a dry season. The average annual temperature in Zagreb is $11^{\circ} \mathrm{C}$. The warmest month, on average, is July with an average temperature of $21^{\circ} \mathrm{C}$. The coolest month, on average, is January, with an average temperature of $0^{\circ} \mathrm{C}$. The average high temperatures are the highest in July and August $\left(27.2^{\circ} \mathrm{C}\right)$ and the average lowest temperatures are $-2.8^{\circ} \mathrm{C}$ and $-1.1^{\circ} \mathrm{C}$ in January and February retrospectively. The average annual amount of precipitation is $882 \mathrm{~mm}$.

\section{Analysis of time series data on Sava River and groundwater temperatures}

Data on the groundwater temperatures and Sava River temperatures in the Samobor-Zaprešić and Zagreb aquifer system areas were analysed. The available time series data of groundwater temperatures included measurements from 472 piezometers in the Samobor-Zaprešić and Zagreb aquifer area, between 1991 and 2010. For the analysis of the Sava River temperatures, we used measurements at the hydrological stations Jesenice (1964 - 1990), Podsused - Žičara (1980 - 1986), Zagreb (1953 - 1989, 2003 - 2010) and Rugvica (1948. - 1995) (see Figure 3). Groundwater temperature measurements in this area are performed by the Croatian Meteorological and Hydrological Service (DHMZ) and Vodoopskrba i odvodnja d.o.o., while the Sava River temperature measurements for the above hydrological stations are accumulated by the Croatian Meteorological and Hydrological Service. The data time series is organized and processed through Microsoft Excel software and purpose-built algorithms in the Visual Basic for Applications (VBA) programming language. From 472 piezometers that have measurements from 1991 to 2010, 183 


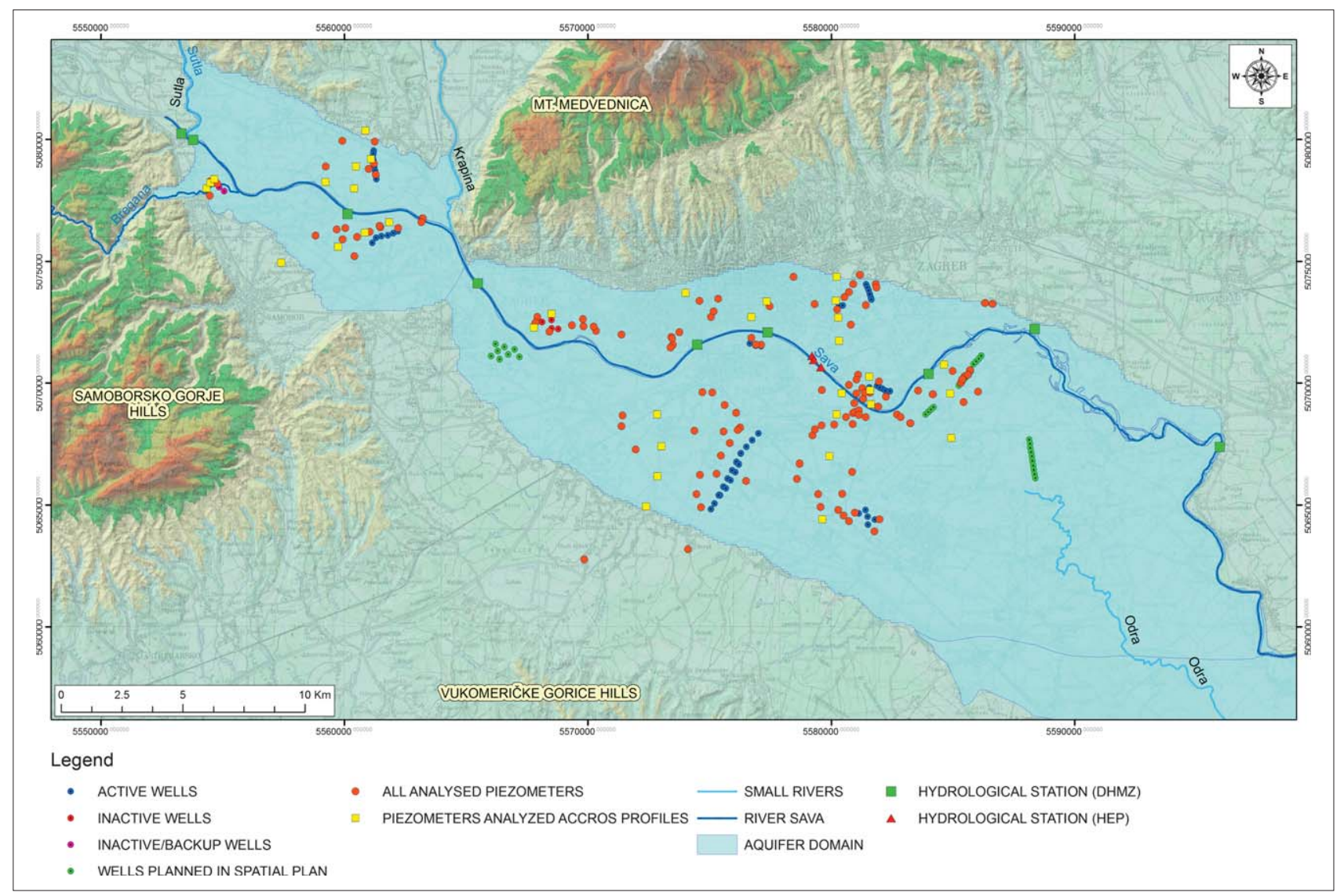

Figure 3. Investigated areal view of the analyzed hydrological observing stations and piezometers

piezometers, which had continuous measurements from 2003 to 2010, were selected (see Figure 3). Further, piezometers in a series of profiles from west to east, approximately perpendicular to the Sava River flow, were selected and correlation and regression analysis of groundwater temperatures and Sava River temperatures was performed. The correlation analysis, in addition to the Sava River and groundwater relationship, was also made with daily measurements for the following hydrological station pairs: Jesenice - Podsused Žičara on the time series data from 1980 to 1986, Jesenice - Zagreb for the period from 1964 to 1989, Jesenice - Rugvica for the period from 1964 to 1990 , Podsused Žičara - Zagreb for the period from 1980 to 1986 , Podsused Žičara Rugvica for the period from 1980 to 1986, and Zagreb - Rugvica for the period from 1954 to 1989 . The aim was to identify possible temperature discrepancies along the Sava River flow.

Although temperatures of the Sava River were measured at nine hydrological stations (see Figure 3), there is a negligible difference in the obtained temperature data. Therefore, in the presented analysis, the Sava River was treated as an isotherm by implementing virtual hydrological stations along the river flow.

Regression analysis of the Sava River temperature and groundwater temperature was conducted to investigate the hypothesis, according to which the degree of connection between these two variables weakens with distance from the river. Based on that hypothesis, we assume that the groundwater temperature forecasts, using measured Sava River temperatures, are only possible in the vicinity of the Sava River. By comparing Sava River water levels and groundwater levels measured in piezometers near the river flow, Posavec (2006) and Bačani and Posavec (2009) observed a remarkably good connection between the Sava River water level and groundwater level. Analogously, we assumed that there is a good connection between the Sava River temperature and the groundwater temperature. Proving this hypothesis is a problem since the frequency of groundwater temperature measurements is once a month or less.

In addition to the statistical analysis, isotherm maps of groundwater temperatures for the summer and winter periods were constructed for all the analyzed years. The temperatures of the Sava River at the hydrological stations and virtual hydrological stations were included in the interpolation. Since measurements are infrequent, for the summer period analysis we selected temperatures measured on the date closest to August 1, but within the period from July $15^{\text {th }}$ to August $15^{\text {th }}$. For the winter period, groundwater temperature measurement dates were closest to February $1^{\text {st }}$, in the period between January $15^{\text {th }}$ and February $15^{\text {th }}$. Also, the maximum, average and minimum groundwater temperatures as well as variation 


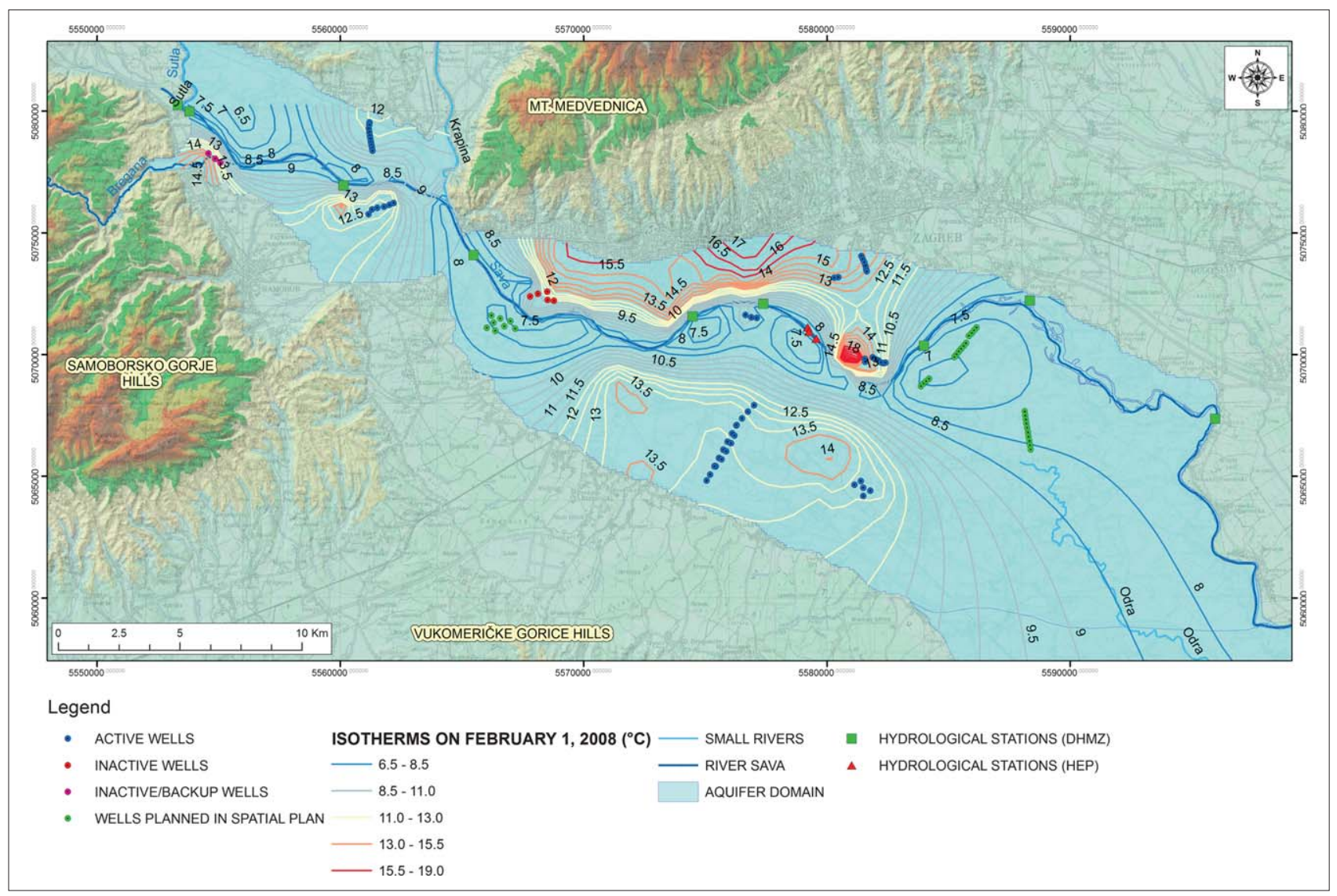

Figure 4. Isotherms of the groundwater temperature for the winter period on February $\mathbf{1}^{\text {st }}, 2008$.

coefficients were analyzed within the available time series. Corresponding isotherm maps were created with the aim of determining the temperature anomalies in the aquifers. Based on the variation coefficient, the temperature variability for a particular piezometer and the reliability of the statistical parameter of arithmetic mean could be determined.

\section{Results based on groundwater temperature analysis}

Correlation analysis of daily Sava River temperatures, measured at hydrological stations along the flow, resulted in correlation coefficients in the range from 0.958 to 0.993 . These correlation coefficient values indicate that temperatures along the Sava River through the Samobor-Zaprešić and Zagreb aquifers vary in very small ranges for the same measurement dates. Temperature differences on the hydrological station Zagreb, located in the wider city center, and the hydrological station upstream (Jesenice) show that temperatures are on average somewhat higher $\left(0.5^{\circ} \mathrm{C}\right)$ in the urban area. This could be explained by an anthropogenic temperature increase due to the urban environment.

Analysis, by which we tried to establish the interrelationship between the Sava River and groundwater temperatures, showed that correlation and regression coef- ficients are relatively small, which indicates a weak interdependence of these two variables, even in the vicinity of the river. Groundwater temperature fluctuation analysis on piezometers at different distances from the river flow also did not confirm the hypothesis that the greater temperature fluctuations are present near the river flow. Although this may indicate heterogeneity of spatial distribution of temperature anomalies in the aquifer area, the lack of data prevents us from interpreting results of statistical analysis with certainty. Groundwater temperature measurements are conducted within the groundwater sampling procedure for determining its quality. Such samplings are usually done four to eight times a year. A low frequency of groundwater temperature measurements results in the inability of recording actual temperature fluctuations during one hydrological year, as extreme temperatures are not recorded most of the time. Since we could perform correlation and regression analysis with only, on average, quarterly measurements through a period of seven years, it is reasonable to assume that the dependence of these two variables would be stronger in the case of daily or weekly measurements.

When analysing isotherm maps, only the areas well covered by the analysed piezometers should be considered (see Figure 3 for distribution of analysed piezometers). Isotherm maps for the winter and summer period, for all the analysed years (from 2003 to 2010) are very 


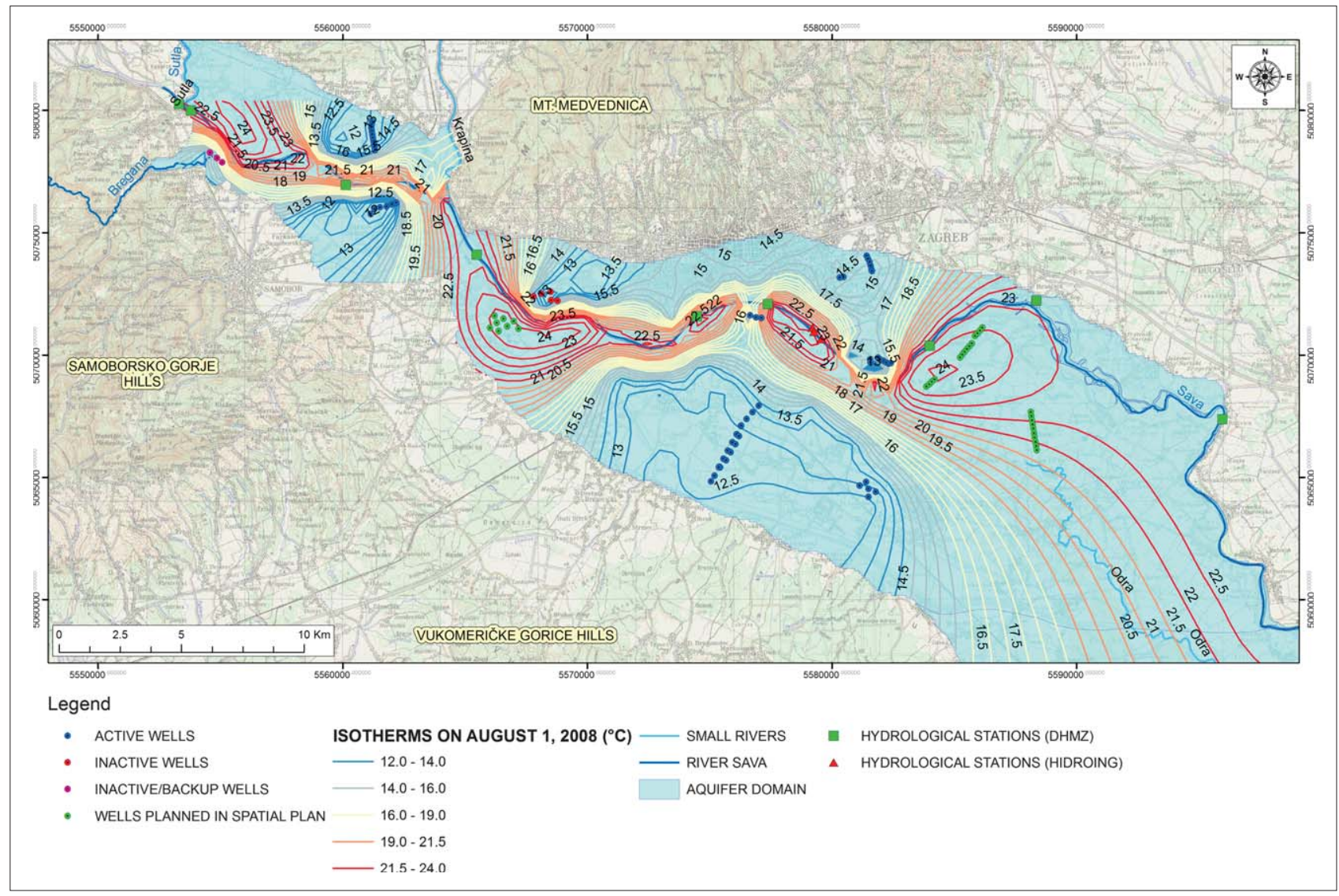

Figure 5. Isotherms of the groundwater temperature for the summer period on August 1 $\mathbf{1}^{\text {st }}, 2008$.

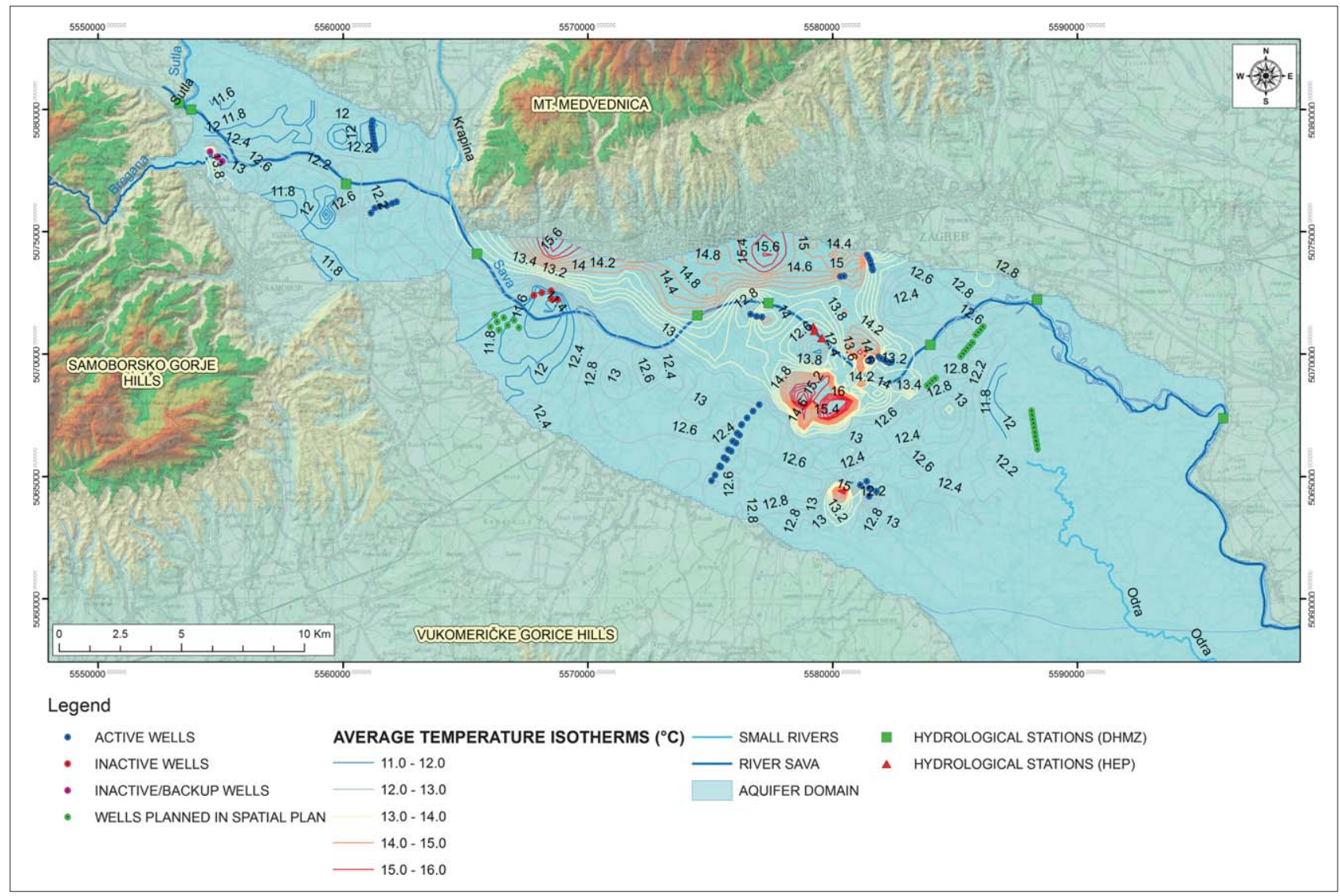

Figure 6. Isotherms of the groundwater average temperature for the year 2008. 
similar. Maps for the year 2008 are shown in Figures 4 and 5. An isotherm map for the winter period, with river temperatures included, shows a relatively low temperature on the right bank of the Sava River, in the Novi Zagreb and Kosnica area. The groundwater temperature in those parts of the Zagreb aquifer is about $6^{\circ} \mathrm{C}$ in the winter period. The maximum groundwater temperature in the winter period is about $18^{\circ} \mathrm{C}$ and occurs on the left bank of the Sava River, west of the Petruševec well field (see Figure 4). The summer period map shows that the minimum groundwater temperature is about $11^{\circ} \mathrm{C}$, and the maximum is about $24^{\circ} \mathrm{C}$, measured along the Sava River flow (see Figure 5). Relatively high temperatures in the summer period are observed in the same areas where a relatively low temperatures are seen in the winter period. The smallest temperature oscillations are in the areas of active well fields and amount to two to three degrees Celsius throughout the year.

The spatial distribution of average temperatures is shown in Figure 6, and the temperature ranges from $10^{\circ} \mathrm{C}$ to $18^{\circ} \mathrm{C}$. It is also seen that the temperature slightly increases downstream of the Samobor-Zaprešić aquifer. The analysis of maximum, average and minimum temperatures showed that the temperature varies the most on the right bank of the Sava River in the Novi Zagreb area, which is confirmed by the highest value of variation coefficient at that location. The results of these analyses, besides providing insight into changes of the Sava River and groundwater temperatures, also indicate the importance of increasing the frequency of groundwater temperature measurement. More frequent measurements would provide data for more reliable groundwater temperature analysis in the Samobor-Zaprešić and Zagreb aquifer systems, which is the main input parameter for geothermal energy use planning.

\section{Energy exploitation of shallow groundwater in an open loop heat pump system}

Open loop heat pump systems use local aquifers as a renewable source of shallow geothermal energy. Thermal energy is extracted from the pumped water at the production well during the winter months in the heat pump heating regime, while during the summer months in the heat pump cooling mode, thermal energy is rejected into the groundwater at the injection well. Unlike in heating mode, during the cooling mode it is not necessary to always use a heat pump compressor. In general, if the groundwater is equal to or below $16^{\circ} \mathrm{C}$, then it can be circulated through a plate heat exchanger and into the building heat distribution system to provide the so-called free or passive cooling. If the temperature of groundwater is higher, or groundwater flow is insufficient for passive cooling, then the heat pump compressor is used to provide active cooling for the building.
The amount of shallow geothermal heat power $\left(\mathrm{Q}_{\mathrm{h} \text { geo }}\right.$ in $\mathrm{kW}$ ) that can be extracted from a groundwater flow is given by:

$$
Q_{\text {hgeo }}=q \cdot c_{w} \cdot \Delta T_{w}
$$

where $q$ is groundwater flow in $1 / \mathrm{s} ; c_{w}$ is the specific heat capacity of water, which equals $4.187 \mathrm{~kJ} / \mathrm{kg}^{\circ} \mathrm{C}$ and $\Delta T_{w}$ is the temperature drop (or rise, in cooling mode) of the groundwater flow in ${ }^{\circ} \mathrm{C}$.

If a heat pump with a coefficient of performance $\left(\mathrm{COP}_{\mathrm{h}}\right)$ is used to extract heat from the groundwater, the total heat power available for space heating $\left(Q_{h}\right.$ in $\left.\mathrm{kW}\right)$ can be derived by:

$$
Q_{h}=Q_{\text {hgeo }}+\frac{Q_{h}}{C O P_{h}}=\frac{q \cdot c_{w} \cdot \Delta T_{w}}{1-\left(1 / C O P_{h}\right)}
$$

In the case of heat rejection into the groundwater during the building cooling regime when a heat pump compressor is operational, the total cooling effect of the groundwater $\left(Q_{c \text { geo }}\right.$ in $\left.\mathrm{kW}\right)$ is the sum of the building cooling energy $\left(\mathscr{Q}_{c}\right.$ in $\left.\mathrm{kW}\right)$ and the waste heat from the compressor (defined with $\mathrm{COP}_{c}$ ) which also must be rejected to the groundwater:

$$
Q_{c}=Q_{c \text { geo }}-\frac{Q_{c}}{C O P_{c}}=\frac{q \cdot c_{w} \cdot \Delta T_{w}}{1+\left(1 / C O P_{c}\right)}
$$

Calculations such as these use a coefficient of performance (COP) representing the instantaneous performance of the heat pump under given temperature conditions. The equations, however, neglect any additional energy used for the operation of submersible pumps in a groundwater well, or circulation pumps of the heat pump circuit. The inclusion of these factors and averaged over an entire heating or cooling season is called seasonal performance factor (SPF).

The design depth and diameter of a groundwater well is dependent on the depth of the aquifer, the groundwater level in the well during pumping and the hydraulic conductivity of the aquifer. The design diameter is also dependent on the yield of the well, which affects the diameter of the required pump. Since groundwater usually contains dissolved minerals, in open loop installation there is a frequent use of plate heat exchangers which separate groundwater flow and an intermediate loop of circulating heat carrier fluid to the heat pumps. As the heat transfer efficiency of the heat exchanger increases (the $\mathrm{U}$ - value increases) and the approach temperature drops, equipment investment costs arise. From an engineering practical aspect, it is feasible to design plate heat exchangers with approach temperatures as low as $1.5-$ $2{ }^{\circ} \mathrm{C}$ difference from the groundwater flow temperature. For ecological and technical reasons (risk of ground settlement in some soils due to prolonged net abstraction, overload of sewage systems, influence on the groundwater table of nearby wells, etc.) re-injection of the ground- 


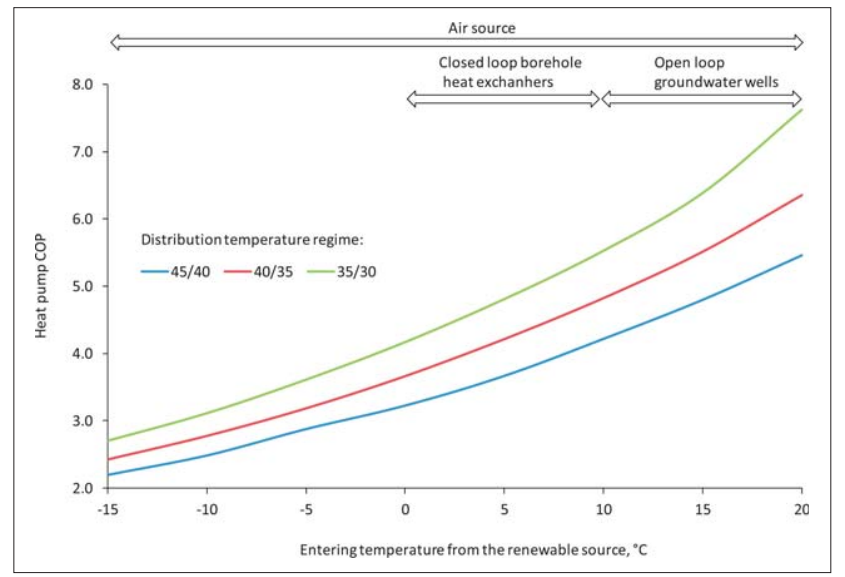

Figure 7. Coefficient of performance for classic brine heat pump unit depending on source temperature and building distribution temperature, according to thermodynamic process analysis (Ecoforest heat pumps technical data www. ecoforest.es) water is regulated by the administrative body (Hrvatske vode).

The main advantages of an open loop heat pump system are the dominant coefficient of performance (COP), since the groundwater temperature is the most favourable renewable source. As seen in Figure 7, for the most efficient heating installation and temperature regime of $35 / 30^{\circ} \mathrm{C}$ (e.g. floor heating), the measure of heat pump delivered useful heat energy units opposed to consumed electricity (COP) is usually higher than 5.5 (for groundwater temperature above $10^{\circ} \mathrm{C}$ ).

However, some disadvantages of groundwater open loop systems can be listed as follows:

- unlike closed loop borehole heat exchangers, which can be installed in almost any geological environment but with variable heat extraction rates dependent on ground thermal conductivity and initial temperature, open loop installations are strictly geo-

Table 1. Installed open loop groundwater heat pump systems in the Zagreb area

\begin{tabular}{|c|c|c|c|c|c|c|}
\hline User & Wells location & $\begin{array}{l}\text { Flow } \\
(1 / s)\end{array}$ & $\begin{array}{l}\text { Heating } \\
\text { power } \\
\text { kWt }\end{array}$ & $\begin{array}{l}\text { Cooling } \\
\text { power } \\
\text { kWt }\end{array}$ & $\begin{array}{l}\text { Heating } \\
\text { energy } \\
\text { GWht/y } \\
\text { (est.) }\end{array}$ & $\begin{array}{l}\text { Cooling } \\
\text { energy } \\
\text { GWhf/y } \\
\text { (est.) }\end{array}$ \\
\hline $\begin{array}{l}\text { IKEA Hrvatska d.o.o., } \\
\text { Ulica Alfreda Nobela 2, Sop }\end{array}$ & $\begin{array}{l}\text { 1711/1 k.o. Hruščica } \\
2 \text { production }+3 \text { injection wells }\end{array}$ & 85 & 2224 & 1483 & 2.669 & 0.741 \\
\hline $\begin{array}{l}\text { EURO Structor d.o.o Zagreb, } \\
\text { Avenija Dubrovnik } 16\end{array}$ & $\begin{array}{l}\text { 847/1 k.o Zaprudski otok } \\
\text { production + injection wells }\end{array}$ & 6 & 157 & 105 & 0.188 & 0.052 \\
\hline MILSING d.o.o. Zagreb, Velika cesta 99 & $\begin{array}{l}\text { 186/3 k.o Gradići } \\
\text { production + injection wells }\end{array}$ & 7.5 & 196 & 131 & 0.236 & 0.065 \\
\hline Private investor, Bregana & $\begin{array}{l}1196 / 2 \text { k.o. Bregana } \\
1 \text { production }+3 \text { injection wells }\end{array}$ & 3.5 & 92 & 61 & 0.110 & 0.031 \\
\hline PIRAMIDA d.o.o. Sesvete, Radnička 10 & $\begin{array}{l}\text { 3001/1 k.o Sesvete Novo } \\
\text { production }+ \text { injection wells }\end{array}$ & 15 & 393 & 262 & 0.471 & 0.131 \\
\hline $\begin{array}{l}\text { FEROIMPEX d.o.o. Bregana, } \\
\text { Strma ulica } 12\end{array}$ & $\begin{array}{l}2470 / 2 \text { k.o. Podsused } \\
2 \text { production }+2 \text { injection wells }\end{array}$ & 9 & 236 & 157 & 0.283 & 0.079 \\
\hline IN DIES d.o.o. Zagreb, Vlaška 70D & $\begin{array}{l}265 \text { k.o. Trnje } \\
\text { production }+ \text { injection wells }\end{array}$ & 5.7 & 149 & 99 & 0.179 & 0.050 \\
\hline $\begin{array}{l}\text { GUMIIMPEX-GRP d.d. } \\
\text { Pavlerka Miškine 64c, Varaždin }\end{array}$ & $\begin{array}{l}843 / 23 \text { k.o. Žitnjak } \\
\text { production + injection wells }\end{array}$ & 10 & 262 & 174 & 0.314 & 0.087 \\
\hline ADIMO d.o.o. Zagreb, Kovinska 5 & $\begin{array}{l}74 / 2 \text { k.o. Brezovica } \\
3 \text { production }+1 \text { injection wells }\end{array}$ & 15 & 393 & 262 & 0.471 & 0.131 \\
\hline $\begin{array}{l}\text { PAP Promet d.o.o. Sveta Nedjelja, } \\
\text { F. Tuđmana } 77\end{array}$ & $\begin{array}{l}234 \text { k.o. Sveta Nedelja } \\
\text { production + injection wells }\end{array}$ & 2.3 & 60 & 40 & 0.072 & 0.020 \\
\hline $\begin{array}{l}\text { ALFA STAN GRUPA d.o.o. Samobor, } \\
\text { Starogradska } 16 \mathrm{a}\end{array}$ & $\begin{array}{l}4821 / 37 \text { k.o. Trnje } \\
2 \text { production }+3 \text { injection wells }\end{array}$ & 26 & 680 & 454 & 0.816 & 0.227 \\
\hline $\begin{array}{l}\text { Palace Hotel Zagreb d.d. Zagreb, } \\
\text { Trg J.J. Strossmayera } 10\end{array}$ & $\begin{array}{l}2508 \text { k.o. Centar } \\
\text { production }+ \text { injection wells }\end{array}$ & 25 & 654 & 436 & 0.785 & 0.218 \\
\hline $\begin{array}{l}\text { City of Velika Gorica, Velika Gorica, } \\
\text { Trg kralja Tomislava } 34\end{array}$ & $\begin{array}{l}\text { 415/1 k.o. Velika Gorica } \\
\text { production + injection wells }\end{array}$ & 5 & 131 & 87 & 0.157 & 0.044 \\
\hline $\begin{array}{l}\text { Croatia Control d.o.o. Velika Gorica, } \\
\text { Rudolfa Fizira } 2\end{array}$ & $\begin{array}{l}\text { 676/1 k.o. Pleso - under } \\
\text { construction }\end{array}$ & 40 & 1047 & 698 & 1.256 & 0.349 \\
\hline \multirow{2}{*}{$\begin{array}{l}\text { The Ministry of Entrepreneurship and Crafts } \\
\text { of the Republic of Croatia, Zagreb, Ulica } \\
\text { grada Vukovara } 78 \text { - SEECEL Kajzerica }\end{array}$} & $\begin{array}{l}\text { 596/9 k.o. Klara - under } \\
\text { construction }\end{array}$ & 25 & 654 & 436 & 0.785 & 0.218 \\
\hline & & Total & 8243 & 5495 & 9.892 & 2.748 \\
\hline
\end{tabular}




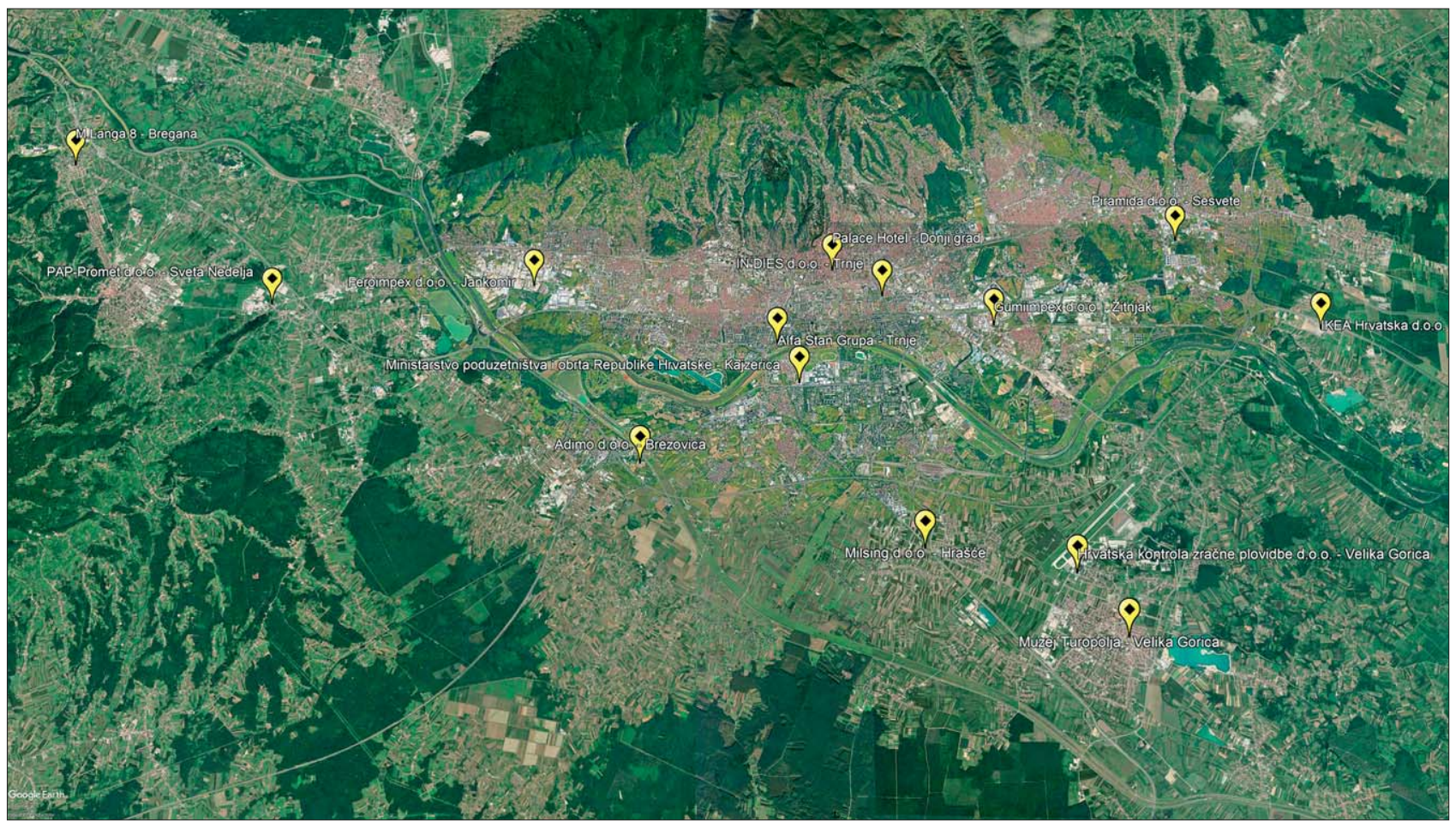

Figure 8. Open loop groundwater heat pump systems in Google Earth ${ }^{\mathrm{TM}}$ database

logically dependent, as they require the existence of an aquifer with favourable hydraulic conditions to provide an adequate yield of groundwater,

- the requirement of a significant degree of design input from a hydrogeologist or groundwater engineer to accomplish optimal heat pump system design and properly constructed, durable water wells, with pump installations, monitoring and control mechanisms,

- significant pumping costs associated with the production of groundwater from deeper wells and generally open loop systems are not economically viable for smaller heating/cooling loads,

- they require formal consent from a regulatory authority to produce and inject groundwater to an aquifer, especially near drinking water production sites. The authorized temperature difference between the production and injection well is $5^{\circ} \mathrm{C}$ due to environmental risks,

- usually some form of fee is required according to regulation for the energy use of groundwater. In the Republic of Croatia, such a fee is set by the Regulation on issuing water rights acts (Narodne novine NN 78/10, 79/13, 9/14) and Regulation on audit of water use fee (NN 82/10, 84/10). It amounts to $0.015 €$ per $\mathrm{m}^{3}$ of produced groundwater (corresponds to roughly $2.3 € / \mathrm{MWh}_{\mathrm{t}}$ for a typical $5^{\circ} \mathrm{C}$ temperature difference in a heat pump system).

- open loop systems have some degree of risk of fouling/clogging of the heat exchanger and production/ injection well by particulate matter, mineral precipitates or biofilms.

\subsection{Overview of open loop heat pump system installations and energy utilization for the Zagreb area}

Unlike in all Member States of EU28, currently there is no regulatory body in the Republic of Croatia that conducts a statistical overview of heat pump installations with shallow geothermal resources, nor consumed energy from such systems. Since geothermal heat pump systems are classified as renewable, there is an urgent need to establish tracking of shallow geothermal energy use, both from closed loop borehole heat exchangers and open loop groundwater systems. In cooperation with the water authority company Hrvatske vode, this paper registered commercial projects with open loop groundwater heat pump systems in the area of the Samobor-Zaprešić and Zagreb aquifers. A project database was made in the Google Earth ${ }^{\mathrm{TM}}$ application, highlighting consumer locations, well depth and technical specifications, lithology column and approved maximum yield. A preliminary assessment on cumulative energy use was made, according to general heat pump operation regimes and efficiency (distribution temperature of $45 / 40^{\circ} \mathrm{C}$ as the most common design) and the average temperature of groundwater according to Figure 6. The final delivered energy was set according to normed groundwater flow from the created database and including equations 1-3. Full load hours of heat pump operation were estimated practically to be 1200 hours for the heating regime and 400 hours for the cooling regime, depending on the climate parameters for the city of Zagreb and a typical building's insulation. Future research should be governed towards 
collecting real energy consumed from the users (where possible) and locate private investors that are using open loop systems (currently not under the Regulation water act).

Google Earth ${ }^{\mathrm{TM}}$ data will be regularly updated with new projects beyond 2018 and it can be downloaded from ResearchGate ${ }^{\mathrm{TM}}$ database under doi: 10.13140/ RG.2.2.12694.40000.

As seen from Table 1, the total installed power for all the obtained project data is $8.2 \mathrm{MW}_{\mathrm{t}}$ for heating and 5.5 $\mathrm{MW}_{\mathrm{f}}$ for cooling. This value is the sum of shallow geothermal heat capacity and heat pump power available to a building as the end user. The estimation of consumed energy for all fifteen discussed projects is $9.9 \mathrm{GWh}_{\mathrm{t}}$ for heating and $2.7 \mathrm{GWh}_{\mathrm{f}}$ for cooling. When geothermal heating energy is transformed to its natural gas equivalent, as a common energy resource in the area, it corresponds roughly to saving 1.2 million $\mathrm{m}^{3}$ of natural gas per year. It is important to mention that the current installed capacity is just a small fragment of the total potential of the aquifer that could be exploited. Restrictions to massive wide use of an aquifer as an energy source are some area limitations for well construction due to numerous sites where drinking water is produced for the city of Zagreb (as seen in Figure 1). Also, new projects under development must prove that the production of water would not affect any other groundwater well installations nearby, from the aspect of changing water table depth due to depression cones forming from pumping. Another negative biological factor which could arise from mass development is the significant influence on static water temperature change in the aquifer.

\section{Conclusions}

The identification of the influence of temperature of the Sava River on the temperature oscillations of the groundwater of the Zagreb and Samobor-Zaprešić aquifers was conducted by statistical analysis of the time series of the Sava River temperature and the temperature of the groundwater by using correlation and linear regression methods. The obtained isotherm maps point to potential areas where geothermal anomalies could have an impact on groundwater temperature oscillations. The isotherm maps also indicated that, with the existence of certain anomalies, the groundwater temperature generally rises in the upstream-downstream direction, from the area of the Samobor-Zaprešic aquifer towards the Zagreb aquifer. The results of these analyses, besides providing an insight into the correlation between the change of the Sava River temperature and the groundwater temperature, also indicate the importance of increasing the frequency of groundwater temperature measurements, as well as other parameters, to provide data for more reliable groundwater analysis of the $\mathrm{Za}-$ greb aquifer. This data is also important for any further shallow geothermal energy system development, as part of a renewable energy growth strategy. A particularly interesting area for the development of open loop heat pump systems is the east and south-east part of the $\mathrm{Za}$ greb aquifer, where the thickness of the aquifer's $1^{\text {st }}$ upper layer is between 25 and $50 \mathrm{~m}$, and the cumulative thickness of both layers is up to $100 \mathrm{~m}$. Therefore, this area provides a significant groundwater yield opportunity per single well which can lower investment costs. Considering the spreading area of the Zagreb aquifer and its currently very low energy utilization status, it can be argued that it has great renewable energy source potential for future exploitation.

\section{References}

Bačani, A. and Posavec, K. (2009): Elaborat zaštitnih zona vodocrpilišta Strmec, Šibice i Bregana (Study of water well protection zones for Strmec, Šibice and Bregana). Unpubl. report. University of Zagreb, Faculty of Mining, Geology and Petroleum Engineering, Zagreb. (in Croatian).

Bačani, A., Posavec, K. and Parlov, J. (2010): Groundwater quantity in the Zagreb aquifer. In: Zuber, A., Kania, J. and Kmiecik, E. (eds.): XXXVIII IAH Congress Groundwater Quality Sustainability, Krakow, September 12-17, 2010, 87-92.

Basch, O. (1983): Osnovna geološka karta SFR J 1:100 000. Tumač za list Ivanić Grad L33-81 (Basic Geological Map of SFRY 1:100 000, Geology of the Ivanić Grad sheet). Geološki zavod, Zagreb, Savezni geolološki zavod, Beograd. (in Croatian)

Kurevija, T., Vulin, D. and Macenić, M., (2014). Impact of geothermal gradient on ground source heat pump system modeling. Rudarsko-Geolosko-Naftni Zbornik (The Mining-Geological-Petroleum Engineering Bulletin), 28, 1, 39-45.

Kurevija, T. (2010). Energetsko vrednovanje plitkih geotermalnih potencijala Republike Hrvatske. (Energetic evaluation of the shallow geothermal potential in the Republic of Croatia). Ph.D. thesis, University of Zagreb, Faculty of mining, geology and petroleum engineering.

Kurevija, T. (2008): Analysis of potentials of shallow geothermal resources in heat pump systems in the city of Zagreb. Goriva i maziva, 47, 5, 373-390.

Posavec, K. (2006): Identifikacija i prognoza minimalnih razina podzemne vode zagrebačkoga aluvijalnog vodonosnika modelima recesijskih krivulja (Identification and prediction of minimum groundwater levels of Zagreb alluvial aquifer using recession curve models). Ph.D. Thesis, University of Zagreb Faculty of Mining, Geology and Petroleum Engineering, Zagreb, Croatia. 96 p. (In Croatian, with English abstract)

Posavec, K., Vukojevic, P., Ratkaj, M., \& Bedenikovic, T. (2017). Cross-correlation Modelling of Surface WaterGroundwater Interaction Using the Excel Spreadsheet Application. Rudarsko-Geolosko-Naftni Zbornik (The MiningGeological-Petroleum Engineering Bulletin), 32, 1, 25.

Šikić, K., Basch, D. and Šimunić, A. (1979): Osnovna geološka karta SFR J 1: 100.000. Tumač za list Zagreb, 138-80 (Ba- 
sic Geological Map of SFRY 1:100 000, Geology of the Zagreb sheet - in Croatian) - Institut za geološka istraživanja, Zagreb, Savezni Geološki zavod, Beograd.

Velić, J., Saftić B. (1991): Subsurface spreading and facies characteristics of middle Pleistocene deposits between Zaprešić and Samobor. Geological Bulletin, 44, 69-82.

Velić, J., Saftić, B. and Malvić, T. (1999): Lithologic composition and stratigraphy of quaternary sediments in the area of the "Jakuševec" waste depository (Zagreb, Northern Croatia). Geologia Croatica, 52, 2, 119-130.

Velić, J. and Durn, G. (1993): Alternating lacustrine-marsh sedimentation and subaerial exposure phases during Qua- ternary: Prečko, Zagreb, Croatia. Geologia Croatica, 46, 1, 71-90.

Vujević, M. and Posavec, K. (2018). Identification of groundwater level decline in zagreb and Samobor-Zaprešić aquifers since the sixties of the twentieth century. RudarskoGeolosko-Naftni Zbornik (The Mining-Geological-Petroleum Engineering Bulletin), 33, 4, 55-64.

\section{Internet sorces:}

Website: www.ecoforest.es, company Ecoforest Geotermia SRL (2018)

\section{SAŽETAK}

\section{Prepoznavanje utjecaja temperature rijeke Save na temperaturu podzemne vode u samoborsko-zaprešićkome vodonosniku te njegov plitki geotermalni potencijal}

Na temelju statističkih analiza vremenskih nizova podataka opisan je utjecaj promjene temperature rijeke Save na promjene temperature podzemne vode zagrebačkoga i samoborsko-zaprešićkoga vodonosnika. U analizama su korišteni podatci dnevnih mjerenja temperatura rijeke Save i kvartalnih mjerenja temperatura podzemne vode. Primijenjene su statističke metode korelacije i linearne regresije te su analizirane maksimalne, srednje i minimalne temperature podzemne vode. Rezultati obrade prikazani su u obliku statističkih parametara, dijagrama i karata izotermi. Navedeni podatci nužni su za razvoj plitkih geotermalnih sustava koji koriste podzemne vode kao izvor toplinske energije. Kako je učinkovitost dizalice topline funkcionalno vezana na temperaturu obnovljivoga izvora, analiza temperature podzemnih voda nužna je za predinvesticijske studije i usporedbe različitih izvedbi termotehničkih sustava. Nadalje, sistematično su obrađeni podatci o trenutačno aktivnim sustavima koji koriste podzemne vode kao izvor energije te je procijenjena godišnje utrošena količina energije za grijanje i hlađenje.

\section{Ključne riječi:}

plitka geotermalna energija, temperatura podzemne vode, dizalice topline

\section{Authors contribution}

Josipa Kapuralić (Research Assistant) lead the entire research and together with Kristijan Posavec (Full Professor) provided groundwater temperature analysis described in Chapters 2, 3 and 4. Tomislav Kurevija (Associate Professor) and Marija Macenić (Research Assistant) conducted research related to energy exploitation of the Zagreb aquifer described in Chapter 5 . 